\title{
Midsummer in Salisbury: The Tailors' Guild and Confraternity $1444-1642$
}

\section{AUDREY DOUGLAS}

In 1611, on the afternoon of Sunday 23 June, the tailors' feast day, Bartholomew Tookey, mayor of Salisbury, delivered an order to the wardens of the company to cease profaning the sabbath as hitherto they had done. In spite of short notice, the wardens nevertheless did what they could to comply with the order. Summoned before the mayor two days later, they protested his action. "What they had donne," they claimed, "was donne tyme out of mynde and alwayes approved by the best of the cittye." Tookey disagreed: who were they, he asked, to judge who were the best? What they had done, he insisted, "was abomynable before god And hell gapes for such ydle and prophane fellowes as delyght in it."

The object of Tookey's outrage was the morris dance and drum scheduled to accompany the tailors on Sunday as they processed from evening prayers at the cathedral back to their hall for supper. The wardens' response had been to hold back the procession until services were over in all the city's churches; they also seem to have cancelled the dance that the whole brotherhood, with their wives, normally took part in after supper (note 48 below).

There is a question encapsulated in this incident: how and why did a customary celebration, whose origins go back at least to the mid fifteenth century, end up in the early seventeenth century as the target of public hostility? The answer, primarily, lies scattered in the tailors' own records, and in the changing aspects of Salisbury's religious and economic climate over the intervening years. What follows is an attempt to interpret details of the tailors' midsummer celebration from its first appearance, in 1444, until its suspension after 1642 with the Cromwellian interregnum. 
The city of Salisbury (New Sarum) was founded in 1225 by Bishop Poore; his successors enjoyed seigneurial rights over the city until 1612 when a royal charter of incorporation recognized the de facto independence that the city had by then achieved under its mayor and common assembly. During the period under discussion the population of Salisbury, which had climbed steeply in the first half of the fifteenth century, ranged variously from 6000 to 7000 . From the fourteenth century the city had developed around the manufacture of cloth; by the fifteenth fullers (or tuckers), dyers, weavers and tailors were numbered among its craft guilds. The economic strength of tailors and weavers is reflected in the fact that these two crafts alone secured charters of incorporation for their religious confraternities, enabling each to hold land for the support of its own chantry and priest.

Towards the middle of the fifteenth century the tailors' confraternity moved briefly from the church of St. Thomas at the north end of the High Street into the neighbouring church of St. Edmund. In 1448, however, the notable William Swayne, thrice mayor of Salisbury and-although not himself a tailor-a munificent patron of the confraternity, provided it with a chantry in the south chancel aisle of St. Thomas's, dedicated to the tailors' patron, St. John the Baptist. From then on the confraternity maintained an unbroken association with St. Thomas's throughout the period under discussion. ${ }^{2}$

Records of the tailors' guild are preserved in a series of ledgers that run from approximately 1444 to the early nineteenth century. Only the first five guild books, containing orders, minutes and memoranda of the tailors' periodic assemblies, concern us here. The carliest of these afford two distinct sources for studying the confraternity's observance of its midsummer obit at the feast of the nativity of St. John the Baptist. The first, an ordinance of 1444 , deals mainly with provision of a livery; preparation of the "light" (torches and tapers); collection of payments for the dinner; two ceremonies in the confraternity's chapel on the vigil and feast of St. John; and a subsequent itinerary through the town. The second source, an episcopal confirmation (1462) of a royal charter given in 1461, deals more succinctly with the religious observances, docs not mention the itinerary, but elaborates instead on the order to be kept at the dinner. ${ }^{3}$

The confirmation of 1462 bricfly describes the obit ceremonies held in the tailors' chapel in the church of St. Thomas. On the eve of St. John (23 June) a solemn dirge was sung, the chapel first being strewn with rushes, the saint garlanded with roses, and two tapers lit before him. At ten o'clock 
on the following morning, after matins, mass was celebrated for the fraternity of the occupation. The feast that followed was restricted to one day; for masters, journeymen and apprentices, it was observed with strict attention to degree in precedence, placing and serving. The processional element in this account is confined to one occasion, when the brethren are summoned "to bryng ynne the light" from the chandler's house to the chapel on the morning of the feast (24 June). Ten torches and five tapers were accompanied by the whole craft, the mayor and municipal dignitaries.

The earlier ordinance (1444) emphasizes the respective roles of masters and journeymen, and their separate but associated fellowships. ${ }^{4}$ It outlines a three-day feast, for the masters only, preceding the evening observance in the chapel. On the morning of 24 June the stewards of both masters and journeymen, accompanied by minstrels, went about the town to give notice of the forthcoming ritual. The procession into St. Thomas's is described in the record: the journeymen first, their stewards next, in front of the light, then the masters' stewards followed by the minstrels, and finally the masters themselves with the mayor and other notables. Here, as in the injunctions of 1462 for the feast, strict attention was paid to the demands of hierarchy. ${ }^{5}$

Once mass in the church of St. Thomas was over, the rest of the day belonged to the journeymen. After their own feast, they went with their light, followed by the masters, to St. John the Baptist's chapel at Aylewater (or Ayleswade) bridge on the river Avon, at the southern boundary of the city and the cathedral close. Here, presumably, the journeymen brought in their light. ${ }^{6}$ Thence the whole company proceeded to the cathedral for evensong, sung at the second morrowmass altar; after which, "by ij to geder... in rewle" they went by a designated route to the masters' hall for the journeymen's final drinking and dismissal. The masters' stewards bore the responsibility for all these arrangements, from ordering the torches and tapers to final dismissal.

The ordinance of 1444, then, has a threefold significance. First, it reveals that originally masters and journeymen ate on separate occasions at the time of the feast, respectively before and on 24 June. Second, it supplements the charter's description of the procession that brought the light into the church of St. Thomas, detailing initial publicity given to the event by the stewards and the order observed as the confraternity entered the church. Third, it enlarges the overall processional element to include a customary itinerary: to the chapel at Ayleswade bridge, thence to the cathedral and 


\section{8 / Renaissance and Reformation}

finally (as the record goes) through the High Street, "forth by the Crown" (an inn) and over the pavement of the market to the hall again.

Variations in these two versions, especially evident in the timing and organization of the dinner, suggest that a restructuring of the confraternity took place, probably at the time the charter was granted. The material particularly relevant to our discussion, however, concerns the bringing in of the masters' light to the chapel on the feast day and the subsequent itinerary, during which the journeymen's light was taken to St. John's chapel at the bridge. Centred on obit observances, these two features were integral to the pre-Reformation celcbration, whether or not fully detailed in both sources. ${ }^{7}$ As we shall see, they are also pertinent to discussion of the tailors' celebration in the post-Reformation period.

The tailors' obit was not the only midsummer event. Like other English cities, Salisbury has a late Medieval history of municipal watches. Watches on the eve of the Nativity of St. John the Baptist (the night of 23 June) and on the eve of the apostles St. Peter and St. Paul (the night of 28 June) were inaugurated in 1440.8 The watch on 23 June coincided with the tailors' evening celcbration within the church of St. Thomas-there is no evidence as to how they scheduled the conflicting events.

In 1457, however, there occurred an event long awaited in Salisbury: Osmund, eleventh-century bishop and builder of the first cathedral, in Old Sarum, was finally canonized. In honour of St. Osmund a third watch, for the eve of his translation (the night of $15 \mathrm{July}$ ), was evidently added to the summer roster. The first municipal order referring to this watch occurs in 1481 ; interestingly, it is only in this year that three watches-for the eves of the Nativity of St. John the Baptist, SS. Peter and Paul and St. Osmund-are ever mentioned in the city's ledgers. ${ }^{9}$

The next specific mention of a municipal watch appears in an order for St. Osmund's eve in 1503. The old midsummer watches in June have now disappeared, leaving the tailors' confraternity as sole celcbrant on the night of 23 June and the following day. Their feast, coinciding with the customary observance of midsummer, must therefore have assumed a particular significance, not only for the brethren themselves, but for the citizens of Salisbury, since no other event remained to mark the traditional high point of the old festival calendar.

The procession for St. Osmund's watch in 1503, as recorded in the ledger book, duplicates almost exactly that ordered for the three watches over twenty years before, in $1481 .{ }^{10}$ In each of these years close to three dozen 
crafts are represented in the procession, with the tailors assigned the place of honour immediately before the mayor. Furthermore, the tailors are associated with a "pageant": in 1481 the reference to their place in the procession is followed by the words, "pageant if any"; in 1503 the tailors and the weavers, who immediately precede them, are each mentioned in conjunction with a pageant. The tailors' records refer to St. Osmund's watch in fourteen years in the period from 1520 to 1544, with annual assessments levied from the brethren in its name. The watch was finally abandoned in 1545. ${ }^{11}$ While there is no mention of pageants after 1503 , it is feasible that up until 1545 the tailors continued, from time to time at least, to stage some form of entertainment in the St. Osmund watch.

Between 1462 and 1558 the tailors' books say nothing concerning the midsummer feast. In the middlc years of the reign of Henry VIII, however, municipal orders for feasts seem to be aimed at curtailment of excess expenditure in celebrations of this kind. ${ }^{12}$ Under the leadership of Thomas Cromwell, the later years of the reign saw a strong attempt to purge liturgical practice of many traditional elements associated by reformers with "superstition." In Salisbury processing with torch and tapers had apparently been discontinued by the middle of 1537 , according to an order in the city's ledger that all crafts keep their feast one day only, "at the time they used to bring in their light." Episcopal injunctions issued for the city in 1538 banned night watches in church, adornment of images, kneeling to them and the offering of worship, candles and gifts. ${ }^{13}$ With subsequent legislation for the dissolution of the chantries (1547 and 1548), and resulting confiscation of chantry goods and revenues, the end was in sight for the commemorative obit that had hitherto been the focus of the old religious confraternities. For the tailors it meant the loss of their chantry in the church of St. Thomas; the chantry chapel of St. John at Ayleswade bridge, to which the journeymen had taken their light, was also suppressed at this time, and the abandoned chapel eventually became a dwelling. ${ }^{14}$

The death of Edward VI and the succession of Mary, a Catholic, allowed only a bricf return to traditional practicc. The municipal confraternity of St. George resumed its obit and feast in 1556 ("let down" since the beginning of the reign of Edward VI); this was a politic move in the wake of the trial in Salisbury of three Protestants who were subsequently burned at Fisherton Field outside the city. About this time the tailors made preparations for their customary third obit, on the decollation of St. John (29 August); and at the end of Mary's reign they ordered their customary midsummer 
celebration to be held, probably for the last time, with evening and morning observances, bringing in of the light, and feast. ${ }^{15}$

The Elizabethan religious settlement, though an attempted compromise with traditional religious practice, nevertheless put an end to any idea of permanent restoration. An order in 1561 that every master of the tailors' occupation reassign his former subscription to the light (18d.) to the midsummer dinner (thus covering the cost of himself and his wife) symbolized the passing of the old religious confraternity, dedicated to the perpetuity of the brotherhood (and sisterhood), in this world and the next. ${ }^{16}$ The Baptist himself left only the name and date of his feast as seasonal reminder of the occupation's roots; and the old dirge and mass gave way to morning and evening services on the day of the feast-and the preaching of some "honest and learned man"-that suited the temper of the times. More intriguing, a new midsummer element emerges in the form of a pageant that owes more to the need to reaffirm the tailors' status within the city than to the celebration of a religious occasion.

Henceforward the date of the tailors' feast, though often assigned in relation to the old patronal day, was normally set for the first or second week after 24 June; in later years it was deferred until the close of the county assizes. ${ }^{17}$ The charge of sabbath-breaking was avoided after 1611 by shifting the feast one day forward so that the principal day fell on Monday rather than Sunday. For, from 1580 to 1635 , the celcbration evidently extended to two days-each with a meal-in which the whole occupation from masters to apprentices probably participated, on the inclusive model laid down in the charter of $1462 .{ }^{18}$ The journeymen stewards, for instance, being "slack" in 1573, were ordered to serve at the accustomed feast as befitting their office; one of their responsibilities, according to the charter provisions of 1462, was to serve the masters at each course, before sitting down to eat themselves. ${ }^{19}$ Occasionally the masters contributed money towards the journeymen's feast. This was done in a context that suggests the latter were normally responsible for providing their own food at the general feast rather than that they met to eat on a separate occasion. ${ }^{20}$

The first specific reference in the tailors' books to a post-Reformation pageant or entertainment occurs in relation to the feast ordered for 4 July 1568: the stewards were charged, "now and hereafter," with finding the morris players, and providing meat, drink and wages. In 1569, "being a dear year," they were allowed 10s. to find ten persons to do service in "our accustomed pageant." 21 Later references are suggestive of its content. In 
1570 , for the first time, there is mention in a covenanted agreement of the giant and his bearer, together with three black boys and "one to play the devil's part" - these have respectively three pairs of breeches and "apparell" (not detailed), all described as appurtenances to the giant. Other gear is catalogued at time of audit (usually in February): in 1573 the chamberlain produces a hobby horse, one Maid Marian's coat with kirtle, a girdle of crimson sarsenet, a cloak and a velvet cap; in 1575 two cowls are added to this list; later on a feather (1576-presumably for the cap), an iron hearth "to make fire" (1577), and a staff (1578). ${ }^{22}$ References of this kind continue variously into the seventeenth century, but the context and timing of their incidence-not to mention the usual gaps and ambivalence in the recordraise several questions about the overall history of the event.

From the foregoing entries it appears there were two components in the pageant at this time: first, the giant, with attendant black boys and devil; second, the morris dancers, with Maid Marian, the hobby horse, and perhaps two persons (one managing the hobby horse, and one the "fire"?) for whom the cowls were kept. The earliest reference to morris coats and bells occurs in a lease drawn up in 1564. This must be studied in conjunction with the agreement of 1570 concerning the giant. Both record arrangements made between the brethren of the occupation and one of their fellows, Gregory Clark, a master tailor. ${ }^{23}$

In the first agreement (22 September 1564) Gregory is given custody of five morris coats and twenty dozen "millen" bells for a term of twelve years, paying yearly $3 \mathrm{~s} .4 \mathrm{~d}$. to the occupation. The occupation is to have access to the coats whenever it wishes (implicitly, without payment). In the second agreement (17 July 1570) Gregory undertakes, for five years at his own cost, to "fynde and set goinge in the accustomed pageant of midsomer feaste" giant and bearer, black boys and devil, as well as to assume responsibility for repair of the giant and victuals and wages for all concerned; at the end of the stated term all the items are to be delivered to the corporation in good condition. In return Gregory is to receive 10 s. from the wardens each year at the time of the midsummer feast-the same sum as the stewards received in 1569 in connection with the "pageant" (note 21, above). In November 1575 the occupation orders a view of the apparell for the giant and for the morris, now presumably delivered again by Gregory. ${ }^{24}$ From these agreements Gregory in fact emerges as something of a pageant-master; between 1570 and 1575 he has sole responsibility for maintaining the 
costumes and props of the midsummer pageant, and for all performers except the morris dancers themselves.

From the viewpoint of the provenance of the tailors' midsummer celebrations, however, there is further significance in the details that accompany these arrangements. At the time that Gregory Clark takes custody of the morris gear, "new" morris coats are in part paid for; and the 1570 agreement expressly grants him use of a house and garden "whereas [sic] nowe the sayed gyant standethe." Furthermore, Gregory is entitled to call, gratis, on others of the occupation for "newe soinge" of the giant's coat. ${ }^{25}$

The tenor of these details points not to a totally new circumstance, but to a nostalgic revival of activities that were once familiar to the older members of the occupation. A mouldering giant, standing in a local garden, his coat in bad repair; morris coats in need of replacement-these were certainly not circumstances conducive to the tailors' good reputation. On the other hand the Elizabethan religious settlement offered a new but still tolerant regime; and the membership of the occupation, after a falling off period towards the end of Henry's reign, was on the increase. ${ }^{26}$ Clearly, the 1560 s saw a consciously evolving policy on the tailors' part to restore the public image of their occupation with the re-establishment of once customary practice; in 1570 the agreement with Gregory Clark neatly tied up most aspects of the pageant for the next five years.

What we do not know for certain is when and where the pageant originated. The reference in the agreement of 1570 to "the accustomed pageant of midsomer feaste" does not necessarily mean that giant and morris had a longstanding connection with the feast; "custom" in Medieval and Renaissance parlance could be founded on quite meagre precedent, in this case possibly limited to a few occasions in the $1560 \mathrm{~s}$.

From the beginning the cost factor seems to have been crucial in the maintenance of the giant-one reason, we may suspect, that his upkeep was contracted out in the first place. After a decision in May 1579 that the giant be "lette downe... by cause of the charge which he causethe yearely to this companie," Gregory Clark came forward in June to take him on once more; this time he was to receive 15 s. per annum and the obligation was for life. ${ }^{27}$ Twelve months later Gregory apparently repented of this rash decision; the tailors' assembly agreed that the giant, before being abandoned, go one more year (in reference to 1580 or 1581 , depending on interpretation). In 1582 the occupation finally ordered that "the giant be no more used." As if to emphasize this decision the annual sum of $15 \mathrm{~s}$. formerly assigned to 
Gregory for his maintenance of the giant (note 27, above) was now granted to the stewards, who were primarily responsible for the costs of the feast itself and of the morris dancers. ${ }^{28}$

The onerous cost of the giant is one detail in a worsening economic climate, as changes in the cloth industry brought dislocation and poverty to the city in the last decades of the sixteenth century. The replacement of kersey and rays by broadcloth as the staple manufacture, the decline of Southampton as the principal outlet for trade (now giving way to London) and an overall depression in the Wiltshire cloth industry were contributory factors. A workhouse was established for the city in 1564, and schemes were initiated to further employment, apprentice children and make loans to poor tradesmen. ${ }^{29}$ Understandably, the tailors' records themselves reveal tension and unrest within the occupation. ${ }^{30}$

The later years of the sixteenth century were also a time of increasing puritanism on the English religious and social scene. In spite of repression a strong minority expressed its dissent, from outright attacks on the ecclesiastical settlement to dissatisfaction with liturgical practice and demands for a strict code of conduct in private and public life. In Salisbury, the puritanical outburst of the mayor in 1611 nicely coincided with public policy as expressed in municipal legislation. ${ }^{31}$ In fact, in time of poverty, puritanism at the local government level was easily allied to sentiment that decried waste and undue extravagance on public occasions. Hence, in his dispute with the tailors, probably as many of "the best" sided with the mayor as with the occupation itself.

One other development must be mentioned here. In 1583, according to the city ledger, a horse race took place "at the furzes," near Harnham Hill, well attended by nobles and gentry. The horse race was thereafter staged regularly throughout the period. The prize, a golden bell worth $£ 50$ donated by the earl of Cumberland, was by 1602 supplemented by a golden snaffle, the gift of the earl of Essex. This new event may to some extent have drained interest away from whatever entertainment accompanied the tailors' midsummer festivities, if only because horse racing provided a focus of aristocratic (and therefore wealthy) patronage which the city sorely needed and evidently took pains to attract. ${ }^{32}$

In 1612 Salisbury and its occupations received a fresh start with the grant of a charter that freed the city from the last vestiges of episcopal control. Over the next few years the occupations were formed into companies, their constitutions officially confirmed by the mayor. The corporation itself went 
on to take an active interest in preserving the companies' rights and privileges within the city. ${ }^{33}$

As for the tailors' pageant, the giant is not mentioned again in their books until 1625 , when a bout of plague in the city apparently prompts an order that "there shall not be anie money paied or laied out for the chardge of the Gyant or hobbyhorse Dances for this year." In 1627 the mayor, John Ivie, forbade the tailors to hold their feast because of a continuing or renewed outbreak; while most of the brethren had fled the city, six insisted on keeping the feast, according to Ivic, five of whom later died. ${ }^{34}$ Seven years later, in 1632, the tailors order that the giant and morris dance "goe at the ffeaste as in tymes past." 35 At most these two orders suggest a revival of the giant in the later years of James I, cut short when plague visited the city in 1625 , and not resumed perhaps until 1632. The evidence is too limited, however, to warrant the assumption that the giant was frequently paraded at midsummer during the early decades of the seventeenth century.

While cost was also a factor in the morris dance, the tailors seem to have clung stubbornly to this particular "ancient custom." Specific references (discussed below) to the morris dance or apparell, and in one case to music, appear in nineteen years in the period between 1564 and 1632. More cryptic are various allusions to "our ancient sports" in 1633 and 1641.36 There is an indication that in 1633 these were synonymous at least with the morris dance: immediately following the reference to "ancient sports" is the record of a fine of 5s. imposed on Christopher Smith for scoffing at the wardens, saying, "Pray make an Order that every one of this Company may weare Belles on their legges." Not every member of the company, it seems, approved the morris dance!

One reason the dance persisted was that the occupation was largely able to tie the cost (almost inevitably incurring personal expenditure) to the stewards' office. ${ }^{37}$ Expenses for the feast, including the preacher's dinner, similarly fell to the stewards, though all who attended made payments per head or per couple (occasionally for servants or children), according to degree. The chamber of the occupation offered grudging help, at first by enabling the stewards to borrow from the occupation's stock, with repayment at the end of their term of office; and later by allowing them a fixed payment of $£ 3$ secured by bonds. Instituted in 1586, this allowance continued until 1636 when it was cut to $£ 2 .{ }^{38}$

Not surprisingly, stewards'occasionally rebelled. In 1578 Roger Luxmore, though quarrelling with the whole system then in force ("this bargain he 
liked not"), was willing to contribute 20s. of his own if the occupation itself disbursed money for the feast. This stand earned him dismissal from office and a fine. Robert Martin, another occupation member, stepped in to cover the costs, later obtaining as judicious reward the return of goods that he had in pawn to the occupation and partial remission of a debt. The next year the occupation shared the costs, paying the dancers' wages, while the stewards found their meat and drink. ${ }^{39}$ No money was initially allocated in 1589 - the stewards eventually secured a 40 s. contribution to the feast, which was postponed, presumably as a consequence of their protest, from 29 June to 6 July. 40

Unhappily for the stewards, it was the chamberlains who had custody of the morris apparcll so that the income that could evidently be made by renting it out went to the profit of the chamber. On occasion the morris gear was farmed out, as to Gregory Clark in 1564, for a fixed term. In 1584 Thomas Barker, a former steward, covenanted to pay 2s. $6 \mathrm{~d}$. per annum for a term of ten years, for the morris and Maid Marian coats, 13 score bells with leathers, velvet cap, hobby horse and his furniture, and all other appurtenances; the occupation was to use all freely, as it wished. The morris gear as a source of rental profit is an interesting indication that the tailors were not the only employers of morris dancers in the local area, though they probably had a monopoly in what was necessary to fit them out, the more so since through the occupation they effectually controlled what went on in the city's clothing industry. ${ }^{41}$

There is no single detailed description of the tailors' midsummer celebration in the post-Reformation period comparable to the record available for the fifteenth century. From what evidence there is, however, it is possible to piece together a hypothetical outline, as follows:

\section{First Day}

1. a morning service at the church of St. Thomas; ${ }^{42}$ including

2. delivery of a sermon; 43

3. a feast or dinner at the tailors' hall; 44

4. a procession to St. John's chapcl at Ayleswade bridge; 45

5. evening prayer at the cathedral of the Blessed Virgin Mary; ${ }^{46}$

6. a procession to the tailors' hall for supper; ${ }^{47}$ followed by

7. dancing; 48

\section{Second Day}
8. a service at the church of St. Thomas; ${ }^{49}$
9. supper and dance at tailors' hall. ${ }^{50}$ 
Obviously not every event in this schedule is demonstrable for every year. Even so, the material is suggestive of customary events-attendance at St. Thomas and the cathedral, visiting the chapel at the bridge-that date back to the fifteenth century.

Evidence from 1611 shows that the tailors, as in the past, continued to process from cathedral to hall on the evening of their principal feast day. The route itself probably varied over the years, if only because the location of the hall changed at least three times. In 1444, when the route was first described, the tailors had a hall in the churchyard of St. Thomas, near the market. From 1451 to 1533 they had their mectings at Greyfriars, south of St. Ann Street-Greyfriars lay east of the cathedral and was certainly not directly on the route that went by way of the High Street towards the market. In 1533 they built a house at the northwest corner of Milford and Pennyfarthing streets, east of the market, thereafter known as Tailors' Hall. ${ }^{51}$

The injunction in 1580 stressing that order be kept in coming "from Ste Jones house to wit ffrom Castell gate downward," (note 45 above) is problematic: Castle Gate stood at the north end of the city in Castle Street, while the chapel at Ayleswade bridge lay at the southern boundary. In 1444 the visit to the chapel preceded evensong in the cathedral, a short distance away. We must assume either some error in the 1580 wording (perhaps Harnham Gate, at the southeast of the cathedral close, should be understood for Castle Gate); or that after going to the bridge, the company dispersed, eventually re-forming at the northern end of the city to process to its next location. The visit to the chapel was now merely customary, since it was no longer in use.

As for the giant and morris dance, only tentative conclusions may be reached. We have seen that in the fifteenth century, apart from their own confraternity celcbration, the tailors also participated in midsummer watches; on two of these occasions they are linked to a pageant. Early in Elizabeth's reign they incorporate a giant and morris dance-a pageantinto their midsummer celebration. The origin of the giant and morris, however, cannot be substantiated. As far as the pre-Reformation confraternity celebration is concerned, the emphasis on the entry of the masters' light into St. Thomas's, with attendant procession and dignitaries, as well as the journeymen's into St. John's chapel at the bridge, discounts the possibility that either morris or giant was part of the event: staging these elements at any time on the patronal feast day would have detracted from 
the primary focus on the obit itself. There is room, then, to speculate-and only speculate-that both morris and giant originated in pageants staged by the tailors in one or other of the three pre-Reformation watches. We cannot, however, go as far as writers who enlarge upon this somewhat bleak hypothesis to portray a fullblown serics of pageants such as Stow described for London. 52

From the overall contemporary record, an interesting comparison may be made between the late Medieval and post-Reformation midsummer celebration. The fifteenth-century ordinance portrays the procession into St. Thomas's as the high point of the feast day. At the same time, the tailors' midsummer celebration occurs in a twofold context: religious, in that through performance of dirge and mass confraternity members are knit together in the perpetuity of their brotherhood; public, in that through the itinerant events of the day (from church to hall, to chapel and cathedral, and back to hall) the tailors and thcir occupation affirm their status within the city.

The post-Reformation celebration shares these aspects: attendance at church and cathedral together with some form of itinerary through the city still convey the religious and public aspect of the event. The high point has shifted, however-no longer the entry into St. Thomas's, but the exit from the cathedral at the end of the principal feast day. If the 1611 account is to be trusted, the order and degree that characterized the former is replaced in the latter by a disorderly rout, with taunts and reproaches hurled at the procession and rowdy apprentices making suitable response. The high point of the celebration then no longer anticipates a religious observance but a supper and dance at Tailors' Hall; it embodies a loosening of restraint rather than a disciplined preparation. In other words, the event has shifted to a context that is primarily secular rather than religious. Perpetuity is affirmed in a customary and itinerant round of events in which "ancient sports" have an increasingly antique role. While the giant reappears through succeeding centuries to celebrate occasions of national rejoicing, it is as the Salisbury Giant, an emblem of the city rather than the guild. Purchased by the city's museum in 1873, his last public outing was in 1977. Now, at home in the muscum in the Close, he enjoys a stationary retirement. ${ }^{53}$

\section{Records of Early English Drama, University of Toronto}

\section{Notes}

1 Public Record Office [P.R.O.], SP14/64 no. 66, f. 89 [hereafter cited as Instructions 1611], endorsed as the tailors' instructions touching their wardens' imprisonment by Bartholomew 
Tookey, mayor; committed to prison, the wardens were released after 2 days, having found sureties to appear at the next quarter sessions; the document is headed "repealed," suggesting eventual acquittal or dropping of charges.

2 Victoria County History, Wiltshire [VCH Wilts], vol. 6 (Oxford University Press: London, 1962), pp. 94, 134.

3 Wiltshire Record Office [W.R.O.], Trowbridge, G23/1/251, Tailors' Guild Book 2 [TGB 2], opens with the ordinance of 1444 (ff. $2 \mathrm{r}-4 \mathrm{v}$ ) and continues intermittently to $1573 ; \mathrm{G} 23 / 1 / 250$, Tailors' Guild Book 1 [TGB 1], contains a confirmation (ff. 8r-10v) of the royal charter granted in 1461 (P.R.O. Calendar of Patent Rolls 1461-7 (London: H.M.S.O., 1897), 55), and subsequent material 1561-1706 (not consecutively written). My thanks to the staff of the Record Office for their kindness and help.

4 VCH Wilts, vol. 6, p. 134.

5 The abbreviation in the record (minstrell') may be read as plural (TGB 2, f. 3v); since each pair of stewards had their own minstrel(s), probably two at least accompanied the procession into the church.

6 The upkeep of the chantry chapel of St. John, situated on an island in the river, and of Aylewater or Ayleswade (later Harnham) bridge was charged to the hospital of St. Nicholas by their builder, Bishop Bingham, in 1244 (VCH Wilts, vol. 6, p. 88). Two priests said mass every day in the chapel, Tuesday being allotted to St. John the Baptist (The Cartulary of St Nicholas' Hospital, Salisbury, ed. Christopher Wordsworth (Salisbury: Brown, 1902), p. 26).

7 TGB 2, ff. $2 \mathrm{v}$ and $4 \mathrm{v}, 1444$, for the confraternity's obits on St. John "ante portam latinam" (St. John's day in May, 6 May) and the decollation of St. John (St. John's day in harvest, 29 August).

8 W.R.O., G23/1/1, Salisbury Corporation Ledger $\Lambda$ [SCL 1]. f. 120r, 1440.

9 W.R.O., G23/1/2, Salisbury Corporation Ledger B [SCL 2], f. 139v, 1481; "accustomed vigils" were ordered in 1474 (SCL 2, f. 115v); the cost of three annual watches and enforcement of attendance was burdensome for municipal and craft authorities.

10 SCL 2, f. 139v, 1481; f. 210r, 1503-new crafts are listed but overall the order is unchanged. Similarity may indicate a deliberate revival in 1503 , with no watches staged in the intervening years.

11 TGB 2, f. 12v, 1520; f. 13v, 1521; f. 13v, 1522; f. 14v, 1526; f. 18r, 1531; f. 24r, 1535; f. 25r, 1537; f. 26r, 1538; f. 27r, 1539; f. 28r, 1540; f. 29r, 1541; f. 30r, 1542; f. 31r, 1543; f. 32v, 1544. The watch was cancelled "for certain causes," i.e. government suppression (SCL 2, f. 299v, 1545).

12 SCL 2, f. $245 \mathrm{v}, 10$ December 1520: henceforth occupations to keep their feasts one day only; f. $248 v, 9$ April 1522: no feast to be held henceforth except for the "George feast" (of the city's merchant guild, in practice its governing assembly)-possibly this order was aimed at private events rivalling the George feast; f. 256v, 11 April 1525: obit and mass of confraternity of St. George to continue, but feast cancelled this year, the city being "greatly charged to the king."

13 SCL 2, f. 283r, 1 June 1537; Robert Benson and Henry Hatcher, Old and New Sarum or Salisbury, History of Modern Wiltshire, ed. Sir Richard Hoare, vol. 6 (London: John Bowyer Nichols, 1843), p. 239.

14 VCH Wilts, vol. 6, p. 88; Royal Commission on Historic Monuments, Ancient and Historical Monuments in Salisbury, vol. 1 (London: H.M.S.O., 1980), p. 45. The occupation lost only the portion of lands and revenues that was assigned to its chantry. The Valor Ecclesiasticus (1535) estimated the value of the tailors' (or Swayne’s) chantry at $£ 1218 \mathrm{~s}$. 10d. with tithes worth 25s. $103 / 4 \mathrm{~d}$.; its goods included an impressive array of vestments (Benson and Hatcher, pp. 264-65, note).

15 SCL 2, f. 314v, 20 March 1556; Benson and Hatcher, p. 272; TGB 1, f. 145v, 19 July, 2 Philip and 3 Mary (an error here), either 1555 or 1556; f. 146r, 5 June 1558.

16 TGB 2, f. $147 \mathrm{v}, 11$ July 1561. 
17 W.R.O., G23/1/254, Tailors' Guild Book 5 [TGB 5], f. 16r, 1635; f. 23v, 1637.

18 W.R.O., G23/1/252, Tailors' Guild Book 3 [TGB 3], f. 25r, 1580, dance after supper "and the next day"; from 1599 (G23/1/253 [TGB 4], f. 15v) orders usually refer to "feasts" (plural), and may assign two days; from 1636 the feast was ordered to be one day only (G23/1/254 [TGB 5], f. 17r), but in 1641 was held for two days (TGB 5, f. 36r).

19 TGB 2, f. 91v; $c$. TGB 1, f. 10r, 1462-apprentices were likewise to serve journeymen.

20 TGB 2, f. 107v, 1573 (folio out of sequence); TGB 3, f. 76r, 1590.

21 TGB 2, f. 61v, 1568; TGB 2, f. 66v, 1569.

22 TGB 2, f. 74v, 1570; f. 90r, 1573; f. 102v, 1575; TGB 3, f. 2r, 1576; f. 8r, 1577; f. 12r, 1578.

23 TGB 2, f. 40r, 1564 (midsummer feast not mentioned); f. 74v, July 1570. Gregory Clark, warden 1573-74 (TGB 2, f. 89v), attended tailors' assemblies from 1559 (TGB 2, f. 33r) to 1607 (TGB 3, f. 53r); he died in 1612 (W.R.O., 1900/5, Register of St. Thomas 1570-1653, burial 20 October).

24 TGB 3, f. 1v: strictly the respective end-limits of the two terms -5 years for the giant and 12 for the morris coats-fell in 1575 and 1576, after midsummer. Possibly Gregory reneged on the 1564 agreement, or the record postdates the start of the working arrangement.

25 TGB 2, rr. 40v and 42r, 1564-new coats are ordered again in 1591, TGB 3, f. 83r; f. 40v, 1570.

26 VCH Wilts, vol. 6, p. 134.

27 TGB 3, fr. 21r, 22r; an outbreak of plague in 1579 does not seem to have had a role in the decision to discontinue the giant; while the ledger does not mention plague until 2 November (W.R.O., G23/1/3, Salisbury Corporation Ledger C [SCL 3], f. 59r), there is a rise in the number of deaths from June to October, peaking in August and September, for a total of $7 \%$ of the population; high rates are also observable for $1563(11 \%)$ and 1604 (17\%)-see John Chandler, Endless Street: A Itistory of Salisbury and Its People (Salisbury: Hobnob Press, 1983), p. 40.

28 TGB 3, f. 25v, 13 May 1580; f. 35r, 15 June 1582.

29 VCH Wilts, vol. 6, pp. 126, 100; for documentation of conditions in the early 17th century, see Poverty in Early Stuart Salisbury, ed. Paul Slack. Wiltshire Record Society, 31 (Devizes, 1975).

30 E.g. TGB 3, f. 14r, 1578, fines for non-attendance at burials and assemblies; f. 17r, suspension from the brotherhood of a troublemaker, f. $18 \mathrm{r}$, an order detailing fines and imprisonment for disobedience to the wardens-repeated f. $61 \mathrm{r}, 1585$.

31 SCL 3, f. 203v, 1608, an order forbidding plays to be performed after 6 p.m. and confiscating the mayor's allowance if he licenses them; repeated f. $247 \mathrm{v}, 1615$.

32 SCL 3, f. 90v, 1585, a memorandum referring to 1583; f. 172r, 1602; in May 1623 the tailors subscribed 50s. towards the race (TGB 4, f. $140 \mathrm{r}$ ).

33 VCH Wilts, vol. 6, pp. 105, 136.

34 TGB 4, f. 151 v, 10 June 1625 ; cf. W.R.O., G23/1/38 no. 89, 29 July 1625 , plague orders issued at the city sessions, including suspension of the city waits' activities and of music in all private and public places; John Ivie. "A Declaration" (London, 1661: reprinted in Slack, Poverty). p. 123: cf. SCL 3, ff. 335v, 337v, 1627, pest houses appointed in the city against the return of the plague. an outbreak that accounted for a mortality rate of $5 \%$ of the population (Chandler, Endless Street, p. 40).

35 TGB 5, f. 6r, 6 June 1632.

36 TGB 5, f. $9 v, 1633$ and f. $36 \mathrm{r}, 1641$.

37 TGB 2, f. 6lv, 1568, stewards to call dancers and find meat, drink and wages; f. 66v, 1569, allowed 10s. to find 10 persons for the pageant: TGB 3, f. $25 \mathrm{r}, 1580$, find diet and wages of dancers; f. 80r, 1591, diet and wages of dancers and musicians; TGB 4, f. 169v, 1628, music and other things. 
38 TGB 3, f. 61r, 1586; TGB 5, f. 17r, 1636-from 1640-42 there is no record of any allowance. Payments for attending the feast are detailed in TGB 2, f. 3v, 1444; TGB 1, f. 147v, 1561; TGB 4, f. 39v, 1603; TGB 5, f. 9r, 1633; f. 31r. 1640.

39 TGB 3, f. 14v, 1578; one, Roger Luxmore, later appears as prison-keeper having custody of the wardens (Instructions 1611); TGB 3, f. 21r, 1579.

40 TGB 3, f. 70r, 1588; ff. 71v-72r, 1589. Individual stewards were disciplined in 1602 for abuse of funds (TGB 4, f. 34v); 1618 for refusing to keep feast (f. 115r); 1632 for refusing to execute office (TGB 5, f. 6r).

41 TGB 3, f. 47r, 1584-Barker was steward 1572-73 (TGB 2, f. 90r). For morris apparell produced at the chamberlains' audit, see note 22, above, and TGB 2, f. 96v, 1574: TGB 4, f. 39v, 1603; f. 121 r, 1619; Nicholas Longman, chamberlain 1602-1603, delivered 5s. $6 \mathrm{~d}$. to the chamber for use of the morris apparell (TGB 4, f. 39v). In 1663, the chamberlains received $5 \mathrm{~s}$. for rent of the morris coats from the men of Downton, a nearby Wiltshire parish (TGB 5, f. 102r).

42 TGB 3, f. 25r, 1589, brethren go with wardens to and from church; keep their place and sit according to seniority. In 1640, however, the company "according to ancient custom," met on Sunday evening at St. Thomas's. before the feast day, and thence returned to their hall: a national fast was in force-solemn assembly and dinner only was held on Monday (TGB 5, f. 31 r, 1640); in 1641, the feast was held on Monday and Tuesday but the company also met at church on Sunday evening (TGB 5, f. 36r).

43 TGB 2, f. 83v, 1571, sum from common chest for honest man preaching sermon; TGB 3, f. $41 \mathrm{r}, 1583$, sermon on Sunday and Monday of midsummer feast: f. $62 \mathrm{r}, 1586$, sermon in St. Thomas's church Sunday and Monday; f. 112v, 1595, stewards to discharge preacher's dinner-specific mention of preacher's dinner most years to 1626 (TGB 4, f. 158r).

44 Mayor sent order (Instructions 1611) to wardens "after dinner" (and before evensong), but company had dispersed and departed-i.e. either the wardens were at home, or still together at the hall after the rest of the occupation had left the dinner; TGB 4, f. 169v, 1628, feast at tailors' hall "in accustomed manner"; TGB 5. f. 39r, 1642, meet at tailors' hall for dinner, return there for supper.

45 TGB 3, f. 25r, 1580, keep same order of seniority (as sitting in church-note 42, above) in coming from St. John's house, that is, from Castle Gate downward.

46 The brethren process to their hall after evening prayer at the cathedral (Instructions 1611); TGB 5, f. 36v, 1641, meet at tailors' hall at 4 p.m., attend wardens and go with them to evening prayer at cathedral.

47 Leaving cathedral, with morris and drum, for hall and supper (Instructions 1611); TGB 5 , f. $36 \mathrm{v}, 1641$, return from cathedral "usual way" to hall; f. 39r, 1642, meet at tailors' hall for dinner, and again for supper.

48 TGB 3, f. $25 \mathrm{v}, 1580$, every brother and sister enter dance after supper; the brethren went to their hall to supper and danced no more nor anywhere else that day (Instructions 1611). In 1591 stewards' costs included wages and diet of musicians (TGB 3, f. 80r) and in 1628 music and other things (TGB 4, f. 169v)-the musicians probably played for the dance after supper as well as the morris.

49 TGB 3, f. 41 r, 1583, sermon on Sunday and Monday: f. 62r, 1586, sermon at St. Thomas's, Sunday and Monday: end-dates for references specifying or implying a two-day celebration are 1580 and 1636 - see note 18 , above.

50 TGB 3, f. $25 \mathrm{v}, 1580$, brethren join dance after supper on feast day and next day after: the brethren danced no more nor anywhere else that day-i.e. Sunday (Instructions 1611). Since it was sabbath-breaking rather than the dance itself that was in dispute, there was nothing to stop the occupation dancing on Monday, the second day of the feast. The narrative, tactfully, omits Monday's events to resume on Tuesday 25 June.

51 VCH Wilts, vol. 6, p. 134; for Tailors' Hall see Royal Commission on Ancient Monuments, Salisbury, vol. 1, p. 94. 
52 E.g. Benson and Hatcher, pp. 211-12, with acknowledgement, freely translate Stow's London material into a Salisbury context $-c f$. John Stow, $A$ Survey of London, intro. Charles Lethbridge Kingsford (1603; reprinted Oxford: Clarendon Press, 1971), vol. 1, pp. 101-103; also Charles Haskins, The Ancient Guilds and Trade Companies of Salisbury (Salisbury: Bennett, 1912), pp. 67-68, "We are told by various writers that upon these occasions the pageants were gorgeous"-followed by an unacknowledged reference to Stow's material; VCH Wilts, vol. 6, p. 135, similarly, attributes "attendant sword and mace-bearers" to the early giant, figures not documented for the centuries under discussion (but see note 53, below). Writing to Thomas Cromwell (1537), to ask if the St. Osmund watch should be continued, the mayor of Salisbury referred to the London watch, but only because each municipal event honoured a locally interred saint (British Library, Ms Harleian 283, f. 146v).

53 The present effigy, an amalgam of periodically renewed parts, consists of a carved wooden face (originally pink), an open wooden frame for the body and flexible canework arms (Hugh Shortt, "The Giant and Hob-Nob," rev. Tiffany Hunt and John Chandler (Salisbury and South Wiltshire Museum, 1982), p. 3). Originally 14 feet high, the figure was carried on its bearer's shoulders. Latterly attendants comprised a yeoman; bearers of sword and mace ("whifflers"); and-the giant's present companion-Hob-Nob, a hobby-like but draconian creature, renowned for its snapping jaws. 